\title{
Students' Interaction and Its Relationship to Their Actions and Verbalized Knowledge during Chemistry Labwork
}

\author{
Michael Skoumios ${ }^{1}$, Nicolaos Passalis ${ }^{2}$ \\ ${ }^{1}$ Department of Primary Education, University of the Aegean, Rhodes, Greece \\ ${ }^{2}$ Science Laboratory Center of Rhodes, Rhodes, Greece \\ Email: skoumios@rhodes.aegean.gr,passniko@otenet.gr
}

Received November $22^{\text {nd }}, 2012$; revised December $28^{\text {th }}, 2012$; accepted January $9^{\text {th }}, 2013$

\begin{abstract}
The present study focuses on the interaction of students during chemistry labwork and investigates its relationship with students' actions that are related to the context of labwork and verbalized knowledge expressed by them. At first, labguides for chemistry labwork were designed and were implemented in three groups of 16-year-old students. The labwork process was videoed in each group of students. Each part of the half-minute videos was analyzed. The analysis identified the types of students' interaction, the categories of their actions that are related to the context of labwork and the categories of their verbalized knowledge throughout the labwork. It emerged that there is a relationship among the types of students' interaction, the categories of their verbalized knowledge and the categories of their actions that are related to the context of labwork. The results of this study affect the designing of labwork activities so that they can become more effective.
\end{abstract}

Keywords: Science Education; Chemistry Learning; Labwork; Students’ Interaction

\section{Introduction}

Labwork is an important and vital part of science education. However, despite the importance attached to labwork, there has been a lot of debate as to its effectiveness (Abrahams \& Millar, 2008; Hodson, 1991; Hofstein \& Lunetta, 2004; Osborne, 1993; Toothacker, 1983; Wellington, 1993). Research on the effectiveness of labwork in school practice is restricted. It has been pointed out that there is need for further study into the labwork process so that the learning outcomes can be improved (Abrahams \& Millar, 2008; Skoumios \& Passalis, 2010). The interaction of students, their actions that are related to labwork context and the verbalized knowledge they express during chemistry labwork are the object of the present research paper.

\section{Theoretical Framework}

Labwork holds a central position in science curricula since early in the nineteenth century. A classical definition of school science labwork is: learning experiences in which students interact with materials or with sources of data to observe and understand the natural world (Lunetta, Hofstein, \& Clough, 2007). Several researchers support that the students benefit from their involvement in this process (Abrahams \& Millar, 2008; Garnet, Garnet, \& Hackling, 1995; Lunetta, 1998; Högström, Ottander, \& Benckert, 2010; Hofstein \& Lunetta, 1982; Hofstein \& Lunetta, 2004; Hucke \& Fischer, 2002; Lazarowitz \& Tamir, 1994; Millar, Tiberghien, \& Le Maréchal, 2002; Pickering, 1980; Tobin, 1990). Research data proves that labwork can significantly contribute to the fulfillment of science education objectives. More specifically, it can be more effective in helping students to construct new knowledge (Gunstone, 1991; Högström et al., 2010; Tiberghien, Veillard, Le Maréchal, Buty, \& Millar, 2001; Tobin, 1990) and develop science skills (Giddings, Hofstein, \& Lunetta, 1991; Hofstein, Navon, Kipnis,
\& Mamlok-Naaman, 2005; Högström et al., 2010). It can also help the development of students' psychomotor skills (manipulative and observational skills) (Hofstein \& Lunetta, 1982; Tobin, 1990). In addition, it can promote students' positive attitudes towards science (Hofstein, Shore, \& Kipnis, 2004; Hofstein \& Lunetta, 1982; 2004; Lazarowitz \& Tamir, 1994) and provide the students with opportunities to develop skills that are related to cooperation and communication (Lazarowitz \& Tamir, 1994).

Despite the contribution of labwork to the fulfillment of science education objectives, several researchers have questioned about the effectiveness of labwork (Abrahams \& Millar, 2008; Hodson, 1991; Hofstein \& Lunetta, 2004; Osborne, 1993; Toothacker, 1983; Wellington, 1993). They claim that labwork in schools is frequently poorly organized, causes confusion, and is not productive, while quite a lot of students consider that what takes place in the laboratory has a minimal contribution to science learning (Hodson, 1991). Osborne (1998) claims that labwork "only has a strictly limited role to play in learning science and that much of it is of little educational value" (p. 156). Furthermore, it is argued that the students are focused more on completing labwork than on learning from labwork (Berry, Mulhall, Gunstone, \& Loughran, 1999; Rop, 1998).

It has been pointed out that there is need for further study on the relationships among labwork, students' written and verbalized knowledge, students' actions that are related to labwork context, interaction of students and science learning (Abrahams \& Millar, 2008; Hofstein \& Lunetta, 2004; Högström et al., 2010; Nakhleh, Polles, \& Malina, 2002; Skoumios \& Passalis, 2010).

In this direction, research has been conducted in which videos from physics labwork carried out by students were analyzed. More specifically, students' actions-concerning the labwork context, such as working with the labguide, manipulating appa- 
ratus, doing measurements and verbalized knowledge, while the students were carrying out labwork, were classified into categories so that the relationship between actions and verbalized knowledge could be studied (Becu-Robinault, 2002; Bisdikian \& Psillos, 2002; Buty, 2002; Hucke \& Fischer, 2002; Sander, Schecker, \& Niedderer, 2002; Theyßen, Aufschnaiter, \& Schumacher, 2002). The analysis used the category-based analysis of videotapes method (CBAV), which is based on the work of Niedderer, Tiberghien, Buty, Haller, Hucke, Sander, Fischer, Schecker, Aufschnaiter and Welzel (1998). Despite the specific differentiations in the above research results, a first common finding was that during labwork the students to a great extent do not use the principles and laws they have been taught in science class. Labwork "was effective in getting students to do what is intended with physical objects, but much less effective in getting them to use the intended scientific ideas to guide their actions and reflect upon the data they collect" (Abrahams \& Millar, 2008: p. 1945). A second common finding is that manipulating apparatus and materials and taking measurements are students' prevailing actions, which take up most of their time (between $50 \%-80 \%$ of time), while the contribution of their actions to enabling them to link practice with theory is minimal. This relationship is considered a measure of effectiveness of a labwork activity (Psillos \& Niedderer, 2002).

With regard to chemistry labwork, Skoumios and Passalis (2010) investigated the relationships between the categories of students' actions that are related to chemistry labwork context and the categories of students' verbalized knowledge. In particular, they studied the contribution of different labwork contexts to the amount of students' verbalizations of chemistry knowledge. It was realised that there is a relationship between the categories of verbalized knowledge and the categories of actions that are related to labwork context. The students who used the labguides in order to write answers to given questions tended to verbalize chemistry knowledge. On the other hand, the students that confined themselves to manipulating apparatus tended to express technical knowledge (knowledge more related to technical apparatus). Also, the contribution of students' actions of taking measurements and using labguides and calculations to verbalizing chemistry knowledge is limited.

However, apart from students' actions and the verbalized knowledge they expressed during labwork, the research has also focused on the role of interactions among students who work in groups carrying out laboratory activities. Roychoudhury and Roth (1996) detected three types of interaction in groups of students carrying out laboratory activities: "symmetric", "asymmetric" and "shifting asymmetric". In "symmetric" interaction the students participate in the discourse similarly, while in "asymmetric" interaction one student monopolizes the discourse or the actions and the rest of the students have a minimal participation. In "shifting asymmetric" interaction one student expresses his/her ideas for a longer period than the other students and then another student continues this role. On the whole, "symmetric" interaction among students is considered more productive, as it provides the students with more opportunities for knowledge co-construction (Oliveira \& Sadler, 2008).

Students' actions, discourse among the students, and the type of interaction during labwork define to a great extent the learning results (Driver, Asoko, Leach, Mortimer, \& Scott, 1994; Duschl \& Osborne, 2002; Roth, 2006). Although the relationship between students' actions and verbalized knowledge dur- ing labwork has been investigated, there is no research on the relationship among students' interaction, actions and verbalized knowledge.

\section{Objective and Research Questions}

The present paper is focused on the interaction among students carrying out chemistry labwork in groups and aims at studying the relationship among their interaction, actions that are related to chemistry labwork context and verbalized knowledge during chemistry labwork. In particular, the present study aims to answer the two following research questions:

1) Is there any relationship between students' interaction and their actions when they are carrying out chemistry labwork?

2) Is there any relationship between students' interaction and their verbalized knowledge when they are carrying out chemistry labwork?

\section{Method}

\section{Design of the Study and Participants}

The research was conducted in three stages. In the first stage, a group of teachers prepared labguides that included chemistry labwork. In the second stage, the labguides were distributed to three groups of 16-year-old students, who came from three Greek high schools and participated in the local preliminary competition European Union Science Olympiad (EUSO). The students had been chosen by their school teachers on the basis of their performance in science learning. Every group included three students. The first (Group I) and the third (Group III) groups comprised two girls and one boy, while the second group (Group II) three girls. The labwork was carried out in a high school laboratory and was videotaped. In the third stage, students' labguides were marked and the videos were analyzed (see "Data Collection and Analysis").

Before proceeding with the labwork, special permission was obtained from the schools' principals and the teachers of the classes. Also, the participating students and their parents were provided with information about the nature, the purposes, the content, the experimental activities, the expected duration, the procedures of the labwork and its evaluation, and their consent was obtained.

\section{Chemistry Laboratory Activities}

The following delineate the chemistry activities the students carried out in a high school laboratory.

1) Preparation of $100 \mathrm{~mL}$ of $\mathrm{C}=.1 \mathrm{M} \mathrm{NaOH}$ Solution

The students were provided with a certain amount of solid $\mathrm{NaOH}, 500 \mathrm{~mL}$ deionized water, and all the necessary equipment for the preparation of a water solution. At first, they had to calculate the mass (in gr) of the solid $\mathrm{NaOH}$ they needed and then to carefully weigh it. Finally, they proceeded to the preparation of the $\mathrm{C}=.1 \mathrm{M} \mathrm{NaOH}$ solution using the equipment provided.

2) Identification of pH Range of An Unknown Solution

The students were provided with two acid-base indicators, i.e. phenolphthalein and methyl orange, test tubes, and an unknown solution. They were also given the $\mathrm{pH}$ range of each indicator and the corresponding color change. By mixing the two indicators with samples of the unknown solution, the students were able to find the $\mathrm{pH}$ range of the unknown solution. 


\section{3) Four Unlabeled Bottles}

Four bottles of water solutions (without labels) were provided to the students. The possible contents of the bottles were solutions of $\mathrm{AgNO}_{3}, \mathrm{NaCl}, \mathrm{KI}$ and $\mathrm{Ca}\left(\mathrm{NO}_{3}\right)_{2}$. The students mixed various combinations of the four solutions and were asked to deduce which bottle contains which solution by observing any precipitation reactions that might occur upon mixing.

\section{Data Collection and Analysis}

The research data included the labguides of the student groups and the videos with the labwork carried out by the three groups of students. The duration of the videos was 135 minutes.

A regards the interaction of students during the labwork, the data analysis showed three types of interaction in line with the context proposed by Roychoudhury and Roth (1996): "symmetric", "asymmetric" and "shifting asymmetric" (Table 1). Each part of the half-minute videos was classified into one of the three above types of interaction.

Students' actions during labwork are coded using seven categories. This system of categories is derived inductively from the data. Its application provides results concerning the time devoted to different laboratory activities. Table 2 shows the CBAV categories for labwork context (Niedderer et al., 1998). In this study the category "interaction with a third person" is not used, because there was no interaction between students and teachers during the laboratory activities.

The CBAV method was developed primarily to examine labwork for evidence of students linking theory to practice. As explained above, Niedderer et al., (1998) therefore developed categories for verbalizing different kinds of knowledge, such as chemistry knowledge or technical knowledge. Table $\mathbf{3}$ gives the CBAV categories used for verbalizations of knowledge during labwork. In the present study, apart from the categories in Table 2, the category "other" $(\mathrm{O})$ was also used in order to involve students' verbal discourse that is not related to the above categories, or the absence of oral discourse.

The above categories of students' interaction, verbalized knowledge and actions were measured every half a minute throughout the projection of the videos.

The video analysis was carried out by two independently working researchers and the percentage of agreement between the two researchers was $96 \%$ for all interaction categories, $94 \%$ for verbalized knowledge categories, and $97 \%$ for the categories of students' actions. The disagreements that arose during the video analysis were settled through discussion.

In order to investigate the relationship between students' in-

Table 1.

Types of students' interaction during labwork, and their descriptions.

\begin{tabular}{cl}
\hline Types of interaction & \multicolumn{1}{c}{ Description } \\
\hline "Symmetric" (S) & $\begin{array}{l}\text { The students participate (on the basis of their ideas and actions) similarly and the work is carried out collectively } \\
\text { by all the members of the group. No student monopolizes the discourse or the actions. } \\
\text { One or more students carry out actions or express their ideas for longer periods than in symmetric interaction. } \\
\text { More specifically, a student directs the interaction for quite a long time, which means that from this point of view } \\
\text { the interaction is asymmetric. The same role is later assumed by another student. }\end{array}$ \\
"Shifting asymmetric" (SA) & A student monopolizes the discourse or the actions, while the others have minimal participation. \\
"Asymmetric" (A) &
\end{tabular}

Table 2.

Categories of students' actions concerning the labwork context, and their descriptions.

\begin{tabular}{cl}
\hline Categories of actions & \\
\hline "Other" (O) & Activities not at all related to the lab \\
\hline "Interaction with a third person" (3.P) & The third person can be the teacher, the tutor, other students, or similar \\
"Labguide" (LG) & Using the labguide \\
"Paper and pencil" (PP) & Using paper and pencil. Students write or read in their own protocol \\
"Manipulation of apparatus" (MA) & Using apparatus and devices. Carrying out experimental set up or preparing a measurement \\
"Measurement" (ME) & $\begin{array}{l}\text { Resources used are apparatus and paper and pencil } \\
\text { "Calculation" CL) }\end{array}$ \\
\hline
\end{tabular}

Table 3.

Categories of students' verbalized knowledge during labwork, and their descriptions.

\begin{tabular}{cc}
\hline Categories of verbalized knowledge & Description \\
\hline "Technical knowledge" (KT) & Students use knowledge more related to technical apparatus. Often related to the handling of apparatus. \\
"Chemistry knowledge" (KC) & Students use chemistry knowledge, e.g. words referring to chemistry. \\
"Technical knowledge and chemistry \\
$\begin{array}{c}\text { knowledge" (KTC) } \\
\text { "Mathematical knowledge" (KM) }\end{array}$ & Students use chemistry knowledge and technical knowledge together. \\
\hline
\end{tabular}


teractions and verbalized knowledge, the frequencies of the types of students' interactions and the categories of their verbalized knowledge were recorded and compared. So as to investigate any differentiations between students' interactions and their actions that are related to labwork context, the types of students' interactions and the categories of their actions were also recorded and compared. Furthermore, any associations were investigated through the $\mathrm{x}^{2}$ test. The determination and interpretation of the associations were based on the values of the $\mathrm{x}^{2}$ test and the standardized residuals (Blalock, 1987; Erickson \& Nosanchuk, 1985). Thus, the size of $x^{2}$ test (taking into account the degrees of freedom of the particular table) serves as a mean to detect the existence of an association. As Blalock (1987) argues, the sum of the squares of the standardized residuals provides a good approximation of the value of $\mathrm{x}^{2}$ test for a contingency table. Furthermore, it becomes evident that cells with large standardized residuals contribute most to the size of $x^{2}$ test, thus being responsible (that is to say the source) for the existence of the association between the variables represented by the dimensions of the table. Therefore, if one establishes the existence of associations on the basis of $x^{2}$ test, a very meaningful way to interpret these associations is provided by the examination of the size of standardized residuals for each cell (the standardized residual for a cell shows the standardized difference between observed and expected value for this cell) (Blalock, 1987).

\section{Results}

\section{Students' Interaction}

Table 4 presents the frequencies and percentages of the types of interaction among students during chemistry labwork for all the student groups. It is evident that the interaction among the students is "symmetric" for quite a long time during the labwork. However, the interaction among the students is "shifting asymmetric" or "asymmetric" for most of the labwork.

\section{Students' Actions}

Table 5 presents the frequencies and percentages of the

Table 4.

Categories of types of interactions among during labwork: frequencies (N, N\%).

\begin{tabular}{ccc}
\hline Types of interaction & N & N\% \\
\hline S & 107 & 39.6 \\
SA & 89 & 33.0 \\
A & 74 & 27.4 \\
\hline
\end{tabular}

categories of students' actions concerning the labwork context for all the student groups. It is evident that for quite a long time during the labwork the students manipulate the apparatus and materials found on their laboratory counter or fill in the labguide of the respective labwork activity. The students devote less time to taking measurements or studying the labguide instructions.

\section{Students' Verbalized Knowledge}

Table 6 presents the frequencies and percentages of the categories of students' verbalized knowledge for all the student groups. The categories "chemistry knowledge" and "technical knowledge and chemistry knowledge" are indications of a link between theory and practice. The percentage of labtime here is $54.2 \%$. The percentage of "technical knowledge" during labtime is also high (41.9\%). Finally, there is a particularly low percentage of "mathematical knowledge" during labtime.

\section{The Relationship between Students’ Interaction and Actions}

Table 7 presents the frequencies and percentages of the types of interaction among the students for each category of students' verbalized knowledge. It is evident that when the interaction

Table 5.

Categories of students' actions during labwork: frequencies (N, N\%).

\begin{tabular}{ccc}
\hline Categories of actions & N & N\% \\
\hline O & 6 & 2.2 \\
LG & 51 & 18.9 \\
PP & 80 & 29.6 \\
MA & 81 & 30.0 \\
ME & 44 & 16.3 \\
CL & 8 & 3.0 \\
\hline
\end{tabular}

\section{Table 6.}

Categories of students' verbalized knowledge during labwork: frequencies (N, N\%).

\begin{tabular}{ccc}
\hline Categories of verbalized knowledge & $\mathrm{N}$ & $\mathrm{N} \%$ \\
\hline $\mathrm{O}$ & 6 & 2.3 \\
$\mathrm{KT}$ & 113 & 41.8 \\
$\mathrm{KC}$ & 84 & 31.1 \\
$\mathrm{KTC}$ & 57 & 21.1 \\
$\mathrm{KM}$ & 10 & 3.7 \\
\hline
\end{tabular}

Table 7.

Types of students' interactions and categories of their actions during labwork: frequencies $(\mathrm{N}, \mathrm{N} \%)$.

\begin{tabular}{|c|c|c|c|c|c|c|}
\hline \multirow{3}{*}{ Types of interaction } & \multicolumn{6}{|c|}{ Categories of actions } \\
\hline & $\mathrm{O}$ & LG & PP & MA & ME & $\mathrm{CL}$ \\
\hline & $\mathrm{N}(\mathrm{N} \%)$ & N (N\%) & N (N\%) & N (N\%) & $\mathrm{N}(\mathrm{N} \%)$ & $\mathrm{N}(\mathrm{N} \%)$ \\
\hline $\mathrm{S}$ & $4(3.7)$ & $16(14.9)$ & $43(41.3)$ & $17(15.9)$ & $22(20.6)$ & $5(4.7)$ \\
\hline SA & $1(1.1)$ & $13(14.6)$ & $27(30.3)$ & $30(33.7)$ & $17(19.1)$ & $1(1.1)$ \\
\hline A & $1(1.4)$ & $22(29.7)$ & $10(13.5)$ & $34(45.9)$ & $5(6.8)$ & $2(2.7)$ \\
\hline
\end{tabular}


among the students of a group is "symmetric", then students' actions are mainly included in the category "paper and pencil" for a great part of their time. When the interaction among the students of a group is "shifting asymmetric", then students' actions are mainly included in the categories "paper and pencil" and "manipulation of apparatus" for a great part of their time. However, when the interaction among the students of a group is "asymmetric", then for a great part of students' time the actions are mainly included in the category "manipulation of apparatus".

In addition, it is evident that there is a statistically significant correlation between the types of interaction ("symmetric", "shifting asymmetric" and "asymmetric") and the categories of students' actions, ("labguide", "paper and pencil", "manipulation of apparatus" and "measurements") $\left(\mathrm{x}^{2}=36.36 \mathrm{df}=6, p\right.$ $<.0001)$. This correlation is due to the following students' tendencies (see Table 8).

- When the interaction among the students is "symmetric", the students tend to complete the labguide instead of manipulating apparatus and materials found on their lab counter.

- On the other hand, when the interaction among the students is "asymmetric", the students tend to read the instructions for carrying out labwork and to manipulate the apparatus and materials found on their lab counter instead of completing the labguide and taking and processing measurements.

\section{The Relationship between Students' Interaction and Verbalized Knowledge}

Table 9 presents the frequencies and percentages of the types of interaction among the students for every category of their verbalized knowledge. It is evident that when the interaction among the students of a group is "symmetric", then in a great part of students' time the knowledge is mainly included in the categories "chemistry knowledge" and "technical and chemistry knowledge". However, when the interaction among the students

Table 8.

Frequencies of the types of students' interaction and categories of students' actions concerning the labwork context and the respective standardized residuals.

\begin{tabular}{ccccc}
\hline \multirow{2}{*}{$\begin{array}{c}\text { Types of } \\
\text { interaction }\end{array}$} & \multicolumn{4}{c}{ Categories of actions } \\
\cline { 2 - 5 } & LG & PP & MA & ME \\
\hline S & $16[-.80]$ & $43[+2.24]$ & $17[-2.52]$ & $22[+1.26]$ \\
SA & $13[-1.04]$ & $27[-.04]$ & $30[+.47]$ & $17[+.53]$ \\
A & $22[+2.09]$ & $10[-2.59]$ & $34[+2.43]$ & $5[-2.06]$ \\
\hline
\end{tabular}

of a group is "shifting asymmetric" or "asymmetric", then in a great part of students' time the verbalized knowledge is mainly included in the category "technical knowledge".

In addition, it is evident that there is a statistically significant correlation between the types of interaction ("symmetric", "shifting asymmetric" and "asymmetric") and the categories of students" verbalized knowledge ("technical knowledge", "chemistry knowledge" and "technical and chemistry knowledge") $\left(\mathrm{x}^{2}=23.97, \mathrm{df}=4, p<.0001\right)$. This correlation is due to the following tendencies of the students (see Table 10).

- When the interaction among the students is "symmetric", the students tend to formulate statements including knowledge that combines the used apparatus and materials with the concepts of chemistry instead of formulating statements including knowledge that refers exclusively to the used apparatus and materials.

- On the other hand, when the interaction among the students is "asymmetric", the students tend to formulate statements including knowledge that refers to the used apparatus and materials instead of formulating statements including knowledge that combines the used apparatus and materials with the concepts of chemistry.

\section{Discussion and Conclusion}

This study aimed to investigate the interaction among the students and its relationship with their verbalized knowledge and actions when they are carrying out chemistry labwork in conditions of competition. Three groups of students (16 years old) carried out chemistry laboratory activities and the entire process was videoed. Each part of the half-minute videos was analyzed and the analysis allowed the detection of the types of interaction among the students, the categories of their actions and the categories of their verbalized knowledge during the labwork.

As for the type of students' interaction, the results of the study show that during chemistry labwork most of the time was occupied by "symmetric" and "shifting asymmetric" interaction among the students. In other words, the students either partici-

Table 10.

Frequencies of the types of students' interaction and categories of students' verbilized knowledge and the respective standardized residuals.

\begin{tabular}{cccc}
\hline \multirow{2}{*}{$\begin{array}{c}\text { Types of } \\
\text { interaction }\end{array}$} & \multicolumn{3}{c}{ Categories of verbalized knowledge } \\
\cline { 2 - 4 } & $\mathrm{KT}$ & $\mathrm{KC}$ & $\mathrm{KTC}$ \\
\hline $\mathrm{S}$ & $30[-2.12]$ & $35[+.68]$ & $34[+2.10]$ \\
$\mathrm{SA}$ & $38[+.18]$ & $23[-.61]$ & $22[+.46]$ \\
$\mathrm{A}$ & $47[+2.29]$ & $22[-.14]$ & $5[-2.96]$ \\
\hline
\end{tabular}

Table 9.

Types of students' interactions and categories of their verbalized knowledge during labwork: frequencies (N, N\%).

\begin{tabular}{|c|c|c|c|c|c|}
\hline \multirow{3}{*}{ Types of interaction } & \multicolumn{5}{|c|}{ Categories of verbalized knowledge } \\
\hline & $\mathrm{O}$ & KT & $\mathrm{KC}$ & KTC & KM \\
\hline & $\mathrm{N}(\mathrm{N} \%)$ & N (N\%) & N (N\%) & $\mathrm{N}(\mathrm{N} \%)$ & $\mathrm{N}(\mathrm{N} \%)$ \\
\hline S & $4(3.7)$ & $30(28.0)$ & $35(32.7)$ & $34(31.8)$ & $4(3.7)$ \\
\hline SA & $2(2.2)$ & $38(42.7)$ & $23(25.8)$ & $22(24.7)$ & $4(4.5)$ \\
\hline A & $0(.0)$ & $47(63.5)$ & $22(29.7)$ & $5(6.8)$ & $0(.0)$ \\
\hline
\end{tabular}


pated similarly in the discourse or one student formulated his/her ideas for a longer period than the others and then another student took up this role. The relatively high percentages of "symmetric" and "shifting asymmetric" interactions, as compared with the percentage of "asymmetric" interaction, could be attributed to the fact that the labwork is carried out in conditions of competition. In the ordinary conditions of the school context the above percentages may be slightly different.

With regard to the time budget the students devoted to working with the different contexts of chemistry labwork, it emerged that most of their time was spent in the "manipulation of apparatus" and in "paper and pencil". A reasonable amount of time was spent in using the labguide "to point what to do" and in taking measurements. These findings befit research findings for physics labwork (Becu-Robinault, 2002; Buty, 2002; Hucke et al., 2002; Sander et al., 2002; Theyßen et al., 2002). It is noting that in the present study the percentage of time spent in using "paper and pencil" (e.g. for writing answers to given questions) is comparatively higher than the corresponding percentage in physics labwork activities, where much of the time is spent in the interaction between the teacher and the students (Becu-Robinault, 2002; Buty, 2002; Hucke et al., 2002; Sander et al., 2002; Theyßen et al., 2002). The above differentiation may be attributed to the absence of interaction between the students and the teachers during chemistry labwork as well as to the chemistry activities themselves. Moreover, in this study the time the students spend in activities not at all related to the lab is considerably shorter, as compared with the corresponding time spent in physics labwork. This differentation may be attributed to the conditions of competition during chemistry labwork. Some physics or chemistry labwork activties need a lot of time for setting up the apparatus and less time for making measurements, while other activities need little time for setting up the apparatus and more time for measurements. Of course, these differences are dependent on the degree to which the setup has been prepared before the students come to the lab, how many problems arise, and how many or what kind of measurements are required in the labguide (Niedderer et al., 1998).

As regards the verbalized knowledge the students formulate while carrying out the labwork, it emerged that for most of their time the students formulated statements that included knowledge related exclusively to the used apparatus and materials, without making any mention of chemistry concepts. This means that the students proceeded with the labwork without necessarily linking practice with theory (Millar et al., 2002) or without "transferring" from the "domain of objects and observables" to the "domain of ideas" (Tiberghien, 2000). The above finding is in line with the results of other research, according to which the link between practice and theory is difficult to be achieved (Becu-Robinault, 2002; Hucke \& Fischer, 2002; Sander, Schecker, \& Niedderer, 2002; Theyßen, Aufschnaiter, \& Schumacher, 2002). The percentage of the categories "chemistry knowledge" and "technical knowledge and chemistry knowledge" is higher than the respective percentage of time in other studies (Becu-Robinault, 2002; Buty, 2002; Hucke et al., 2002; Niedderer et al., 1998; Sander et al., 2002; Theyßen et al., 2002). This could be interpreted as meaning that to link theory to practice as an objective might be fostered better in some cases in labs when the students are in competition (as in this study).

The results of the present study show that the type of interac- tion among the students is related to students' actions during the labwork. In particular, students' "symmetric" interaction is related to the completion of the labguide, while the "asymmetric" interaction is related to the study of the instructions for carrying out the labwork and the manipulation of the apparatus and materials found on the lab counter. Therefore, it emerged that when the students participate (with regard to their verbalized knowledge and actions) similarly and the work is carried out collectively by all the members of the group, then for most of their time they tend to be engaged in completing the labguide and not only in reading the instructions and manipulating the apparatus. The completion of the labguide by the students evidences that the labwork is carried out without problems.

In addition, the type of interaction among the students is related to the verbalized knowledge they expressed during the labwork. More specifically, there was a link between students' "symmetric" interaction and the formulation of statements that include knowledge combining the used apparatus and materials with chemistry concepts. Moreover, there was a link between students' "asymmetric" interaction and the formulation of statements that include knowledge referring exclusively to the used apparatus and materials. Therefore, it emerged that when the students participate (with regard to their verbalized knowledge and actions) similarly and the work is carried out collectively by all the members of the group, then they tend to formulate statements combining the used apparatus and materials with chemistry concepts. This link is both an essential objective of the labwork and a finding in line with research results which showed that the active and similar participation of the students in the discourse promotes dialogical argumentation and the construction of concepts by them (Berland \& Reiser, 2009; Engle \& Conant, 2002; Osborne, Erduran, \& Simon, 2004; Sampson, 2009).

It should be pointed out that the present study involved only three groups of students and this is a restriction with regard to its results. A more comprehensive understanding of the relationships among students' interactions, verbalized knowledge and actions, when the students are carrying out chemistry labwork, should include more groups of students.

Research has proven that the labguide and the way it directs the students affect what the students perceive as important (Becu-Robinault, 2002; Högström et al., 2010) and the overall process of carrying out the labwork (Hucke \& Fischer, 2002; Lunetta, 1998; Millar et al., 2002). In order to increase the time during which the students are in "symmetric" interaction, it is necessary to enrich the labguide with appropriate questions that will encourage the discourse among the students and will promote collective actions. For example, the students should be encouraged to focus their attention on ideas formulated by their peers and suggest answers taking into account these ideas. In addition, it is necessary that the students be encouraged to formulate questions, object to views, suggest alternative ideas, justify their own or their peers' views and organize the discourse. In this direction, the use of actions based on socio-cognitive conflict processes could make a useful contribution (Doise, Mugny, \& Perez, 1998; Levine, Resnick, \& Higgins, 1993; Skoumios, 2009). However, further research is required so that the effect of such actions on students' interactions, actions and verbalized knowledge can be investigated.

Moreover, the labguides should not be as detailed and the experimental settings do not in all cases need to be as complete as they usually are. Planning and designing activities should be 
taken into consideration as an essential goal of the labwork (Hucke \& Fischer, 2002). Laboratory activities include both guided and open-ended activities. The skills required for guided activities are as follows: following instructions, using instruments, collecting and analyzing data, comparing graphs, and writing scientific reports with conclusions. Open-ended activities require posing questions, raising scientific hypotheses, planning the work, examining assumptions, searching for scientific background references, and drawing conclusions. Based on the work of Schwab (1962) and Herron (1971), McComas (1997) described how "openness"- the degree to which students make decisions about the problem, the procedure and/or the answers - is often scarce during laboratory activities. At bottom level, the labguide decides the question or problem the students will investigate, how the students will conduct the investigation, and the validity of the investigation results. The students make a few decisions-other than deciding whether they got the "right answers". On the other hand, at top level the students decide what to investigate, how to investigate it, and how to interpret the results generated. In the present study, the labguide of the labwork belongs in the first category. It would be interesting to study students' interactions, actions and verbalized knowledge and the relationships among them as they raise the degree of openness of the learning environment, and compare them to the results of the present study.

This study contributes to the research on the effectiveness of labwork because its findings shed light on the effect the type of interaction among the students of a group has on the verbalized knowledge they express and the actions they perform while thy are carrying out chemistry labwork. Further study on the relationship among students' interactions, verbalized knowledge and actions, while they are carrying out physics and biology labwork, as well as a comparison between the respective results and the results of the present study is deemed necessary.

\section{REFERENCES}

Abrahams, I., \& Millar, R., (2008). Does practical work really work? A study of the effectiveness of practical work as a teaching and learning method in school science. International Journal of Science Education, 30, 1945-1969. doi:10.1080/09500690701749305

Becu-Robinault, K. (2002). Modelling activities of students during a traditional labwork. In D. Psillos, \& H. Niedderer (Eds.), Teaching and learning in the science laboratory (pp. 51-64). Dordrecht: Kluwer Academic Publishers.

Berland, L., \& Reiser, B. (2009). Making sense of argumentation and explanation. Science Education, 93, 26-55. doi:10.1002/sce.20286

Berry, A., Mulhall, P., Gunstone, R. F., \& Loughran, J. J., (1999). Helping students learn from laboratory work. Australian Science Teachers Journal, 45, 27-31.

Bisdikian, G., \& Psillos, D. (2002). Enhancing the Linking of theoretical Knowledge to physical phenomena by real-time graphing. In D. Psillos, \& H. Niedderer (Eds.), Teaching and learning in the science laboratory (pp. 193-204). Dordrecht: Kluwer Academic Publishers.

Blalock, H. M. (1987). Social statistics, Singapore City: McGraw-Hill.

Buty, C., Tiberghien, A., \& Le Maréchal, J.-F. (2004): Learning hypotheses and an associated tool to design and to analyse teachinglearning sequences. International Journal of Science Education, 26, 579-604. doi:10.1080/09500690310001614735

Buty, C. (2002). Modelling in geometrical optics using a microcomputer. In D. Psillos, \& H. Niedderer (Eds.), Teaching and learning in the science laboratory (pp. 231-242). Dordrecht: Kluwer Academic Publishers.

Doise, W., Mugny, G., \& Perez, J. A. (1998). The social construction of knowledge: Social marking and socio-cognitive conflict. In U. Flick (Ed.), The psychology of the social (pp. 77-90). Cambridge: Cambridge University Press.

Driver, R. H., Asoko, J., Leach, E., Mortimer, P., \& Scott, P. (1994). Constructing scientific knowledge in the classroom, Educational Researcher, 23, 5-12.

Duschl, R., \& Osborne, J. (2002). Supporting and promoting argumentation discourse, Studies in Science Education, 38, 39-72. doi: $10.1080 / 03057260208560187$

Engle, R. A., \& Conant, F. R. (2002). Guiding principles for fostering productive disciplinary engagement: Explaining an emergent argument in a community of learners classroom. Cognition and Instruction, 20, 399-483. doi:10.1207/S1532690XCI2004 1

Erickson, B., \& Nosanchuk, T. (1985). Understanding data. Milton Keynes: Open University Press.

Garnett, P. J., Garnett, P. J., \& Hackling, M. W. (1995). Refocusing the chemistry lab: A case for laboratory-based investigations. Australian Science Teacher Journal, 41, 26-32.

Giddings, G. J., Hofstein, A., \& Lunetta, V. N. (1991). Assessment and evaluation in the science laboratory. In B. E. Woolnough (Ed.). Practical science (pp. 167-178). Milton Keynes: Open University Press.

Gunstone, R. F. (1991). Reconstructing theory from practical experience. In B. E. Woolnough, (Ed.), Practical science (pp. 67-77). Milton Keynes: Open University Press.

Hodson, D. (1991) Practical work in science: Time for a reappraisal. Studies in Science Education, 19, 175-184. doi: $10.1080 / 03057269108559998$

Högström, P., Ottander, C. \& Benckert, S. (2010). Labwork and learning in secondary school chemistry: The importance of teacher and student interaction. Research in Science Education, 40, 505-523. doi: 10.1007/s11165-009-9131-3

Hofstein, A. \& Lunetta, V. N. (1982). The role of the laboratory in science teaching: Neglected aspects of research. Review of Educational Research, 52, 201-217.

Hofstein, A. \& Lunetta, V, N. (2004). The laboratory in science education: Foundation for the 21 st century. Science Education, 88, 28-54. doi: $10.1002 /$ sce. 10106

Hofstein, A., Shore, R., \& Kipnis, M. (2004). Providing high school chemistry students with opportunities to develop learning skills in an inquiry-type laboratory-A case study. International Journal of Science Education, 26, 47-62. doi:10.1080/0950069032000070342

Hofstein, A., Navon, O., Kipnis, M., \& Naaman-Mamlok, R. (2005). Developing students' ability to ask more and better questions resulting from inquiry-type chemistry laboratories. Journal of Research in Science Teaching, 42, 791-806. doi:10.1002/tea.20072

Hucke, L. \& Fischer, H. E. (2002). The link of theory and practice in traditional and in computer-based university laboratory experiments. In D. Psillos, \& H. Niedderer (Eds.), Teaching and learning in the science laboratory (pp. 205-218). Dordrecht: Kluwer Academic Publishers.

Lazarowitz, R., \& Tamir, P. (1994). Research on using laboratory instruction in science. In D. L. Gabel (Ed.), Handbook of research on science teaching and learning (pp. 94-130). New York: Macmillan.

Levine, J. M., Resnick, L. B., \& Higgins, E. T. (1993). Social foundations of cognition. Annual Review of Psychology, 44, 585-612. doi:10.1146/annurev.ps.44.020193.003101

Lunetta, V. N. (1998). The school science laboratory: Historical perspectives and contexts for contemporary teaching. In K. Tobin, \& B. Fraser (Eds.), International handbook of science education (pp. 249-264). Dordrecht: Kluwer. doi:10.1007/978-94-011-4940-2 16

Lunetta, V. N., Hofstein, A., \& Clough, M. (2007), Learning and teaching in the school science laboratory: An analysis of research, theory, and practice. In N. Lederman, \& S. Abel (Eds,), Handbook of research on science education (pp. 393-441). Mahwah, NJ: Lawrence Erlbaum.

McComas, W. E. (1997). The nature of the laboratory experience: A guide for describing, classifying and enhancing hands-on activities. CSTA Journal (spring), 6-9.

Millar, R., Tiberghien, A. \& Le Maréchal, J. F. (2002). Varieties of labwork: A way of profiling labwork tasks. In D. Psillos, \& H. 
Niedderer (Eds.), Teaching and learning in the science laboratory (pp. 9-20). Dordrecht: Kluwer Academic Publishers.

Nakhleh, M. B., Polles, J., \& Malina, E. (2002). Learning chemistry in a laboratory environment. In J. K. Gilbert et al., (Eds.), Chemical education: Towards research-based practice (pp. 69-94). Dordrecht: Kluwer Academic Publishers.

Niedderer, H., Tiberghien, A., Buty, C., Haller, K., Hucke, L., Sander, F., Fischer, H. E., Schecker, H. V., Aufschnaiter, S., \& Welzel, M. (1998). Category Based Analysis of Videotapes from labwork (CBAV) - the method and results from four case studies. Working paper 9 from the European project labwork in science education (Targeted Socio-Economic Research Programme, Project PL 952005).

Oliveira, A. W., \& Sadler, T. D. (2008). Interactive patterns and convergence of meaning during student collaborations in science. Journal of Research in Science Teaching, 45, 634-658. doi:10.1002/tea.20211

Osborne, J. (1993). Alternatives to practical work. School Science Review, 75, 117-123.

Osborne, J., Erduran, S., \& Simon, S. (2004). Enhancing the quality of argument in school science. Journal of Research in Science Teaching, 41, 994-1020. doi:10.1002/tea.20035

Pickering, M. (1980). Are lab courses a waste of time? The Chronicle of Higher Education, 19, 80.

Psillos, D., \& Niedderer, H. (2002). Issues and questions regarding the effectiveness of labwork. In D. Psillos, \& H. Niedderer (Eds.), Teaching and learning in the science laboratory (pp. 21-30), Boston: Kluwer Academic Publishers.

Roth, W.-M. (2006). Learning science: A singular plural perspective. Rotterdam: SensePublishers.

Rop, C. J. (1998). Student perspectives on success in high school chemistry. Journal of Research in Science Teaching, 3, 221-237.

Roychoudhury, A., \& Roth, W.-M. (1996). Interactional processes in a constructivist physics lab. International Journal of Science Education, 18, 423-445. doi:10.1080/0950069960180403

Sampson, V. (2009). The impact of argument-driven inquiry on three scientific practices. The Annual International Conference of the National Association of Research in Science Teaching (NARST). Garden Grove, CA: National Association of Research in Science Teaching.

Sander, F., Schecker, H., \& Niedderer, H. (2002). Computer tools in the
lab-Effects linking theory and experiment. In D. Psillos, \& H. Niedderer (Eds.), Teaching and learning in the science laboratory (pp. 219-230). Dordrecht: Kluwer Academic Publishers.

Schwab, J. (1962). The teaching of science as enquiry. In J. Schwab, \& P. Brandwein (Eds.), The Teaching of Science, Cambridge, MA: Harvard University Press.

Skoumios, M. (2009). The effect of sociocognitive conflict on students' dialogic argumentation about floating and sinking. The International Journal of Environmental and Science Education, 4, 381-399.

Skoumios, M., \& Hatzinikita, V. (2008). Investigating the structure and the content of pupils' written explanations during science teaching sequences focused on conceptual obstacles. Themes in Science and Technology Education, 1, 135-155.

Skoumios, M., \& Passalis, N. (2010). Chemistry laboratory activities: The link between practice and theory. The International Journal of Learning, 17, 101-114.

Theyßen, H. V., Aufschnaiter, S., \& Schumacher, D. (2002). Development and evaluation of a laboratory course in physics for medical students. In D. Psillos, \& H. Niederrer (Eds.), Teaching and learning in the science laboratory (pp. 91-104). Dordrecht: Kluwer Academic Publishers.

Tiberghien, A. (2000) Designing teaching situations in the secondary school. In R. Millar, J. Leach, \& J. Osborne (Eds). Improving science education: The contribution of research (pp. 27-47). Buckingham: Open University Press.

Tiberghien, A., Veillard, L., Le Maréchal, J. F., Buty, C., \& Millar, R. (2001). An analysis of labwork tasks used in science teaching at upper secondary school and university levels in several European countries. Science Education, 85, 483-508. doi:10.1002/sce.1020

Tobin, K. G. (1990). Research on science laboratory activities: In pursuit of better questions and answers to improve learning. School Science and Mathematics, 90, 403-418. doi:10.1111/j.1949-8594.1990.tb17229.x

Toothacker, W. S. (1983). A critical look at introductory laboratory instruction. American Journal of Physics, 51, 516-520. doi:10.1119/1.13220

Wellington, J. (1998). Practical work in science. Time for a reappraisal. In J. Wellington (Ed.). Practical work in school science: Which way now? (pp. 3-15). London: Routledge. doi:10.4324/9780203267059 